\title{
ECONOMIC RELATIONS OF ASEAN (INDONESIA) + CHINA
}

\author{
AFTER AIIB
}

\author{
M. Dudi Hari Saputra
}

\begin{abstract}
This paper purpose is to predict Economic Relations of ASEAN (Indonesia) + China After AIIB (the Asian Infrastructure Investment Bank), answering economic crisis questioned that hit the United States and the European Union in 2009 and is still in the recovery process until now, and has made many of Asian countries particularly East Asia such as China began a diversification of market and investment destination and increase economic cooperation to the other regions (ASEAN), particularly Indonesia. Therefore, at first, this paper tries to analyze China economic relations with Indonesia. Second, the effective rate of China trade and investment in Indonesia. Third, prediction of Indonesia and China economic situation after AIIB cooperation. Indonesia relate governance with national policy, which will be correlated with the level of supranational/regional intergovernmental (regionalism and integration) which aims, among others; financial sector to stimulate research and development, increase the spread of technology, reducing managerial differences in running the business and implementing a system to change for the better.
\end{abstract}




\section{Dinamika Global | Volume 02 | No.01 | Juni 2017}

1) China as Big Trader in Indonesia

a) Regionalism and Integration

ASEAN (Indonesia) is a regional organization to regional countries in Southeast Asia has become one of the superb, because of passion and huge market growths. Premises versus Europe where regionalization needs to be done to create distinctive and protected areas, then in East Asia based on an open membership and global liberalization.

And this form of so-called "open-regionalism" formed within APEC and AIIB, after the financial crisis of 2009, the ASEAN (Indonesia) + China to find its momentum as an "openregionalism". China is to be a liaison utilizing regional and global economy, which makes China was able to establish free trade with the United States and the EU, and at the same time free trade with ASEAN (Indonesia) (Woosik Moon: 2011).

Regionalism and Integration in East Asia initially considered lags behind other regions, although the integration process continues (Chang Jae Lee: 2008). Regionalism East and Southeast Asian region to find its momentum departing from the global crisis centered in the United States and the European Union which has strong trade ties with the East Asian countries that have a high risk to economic growth.

Thus, inter-regional trade is viewed as a potential engine of economic growth. ASEAN (Indonesia) + China is considered representative of this trend (Donghyun Park, Inwon Park, and Gemma Esther B. Estrada: 2012) 


\section{Dinamika Global | Volume 02 | No.01 | Juni 2017}

Therefore, China is trying to expand its influence in financial and infrastructure aspects by AIIB (the Asian Infrastructure Investment Bank) to enlarge the capital pool indispensable for infrastructure development in Asia. As an innovative platform for multilateral cooperation, AIIB will advance Asian financial cooperation under the principle of openness and universal benefits. And China welcomes the participation of other Asian countries in the establishment of AIIB (Zhang Monan, 2015).

b) Implementation and Transformation of ASEAN (Indonesia) +
China

ASEAN (Indonesia) relate governance with national policy, which will be correlated with the level of supranational / regional intergovernmental which aims, among others; financial sector to stimulate research and development, increase the spread of technology, reducing managerial differences in running the business and implementing a system to change for the better (V. Rodriguez and A. Soeparwata: 2012).

ASEAN (Indonesia) shows the crucial role of state and government (state-centric) in promoting the domestic industry to seize a larger market, so as to create growth and prosperity. As well as showing the active role of government in the integration, which was previously regarded as a monopoly of the industry. And ASEAN (Indonesia) seeks to implement PTA (Preferential trade agreements), FDI (foreign direct investment), mergers and acquisitions in order to increase welfare (i.e.: 


\section{Dinamika Global | Volume 02 | No.01 | Juni 2017}

reduce poverty) and competition policy (Toby Kendall and Cillian Ryan: 2009).

Productivity effects of spillovers of China's FDI by AIIB later, which flows into the ASEAN (Indonesia) countries. And the contemporary test results of studies using direct and indirect approaches have shown strong evidence that FDI causes productivity growth in the ASEAN (especially Indonesia) countries, which has a correlation of theoretical predictions regarding the relationship between FDI and productivity overflow (Nathapornpan Piyaareekul Uttama and Nicolas Peridy: 2010).

Competition policy has also brought a change in the dynamic comparative advantage between ASEAN (Indonesia) and China. By using statistical methods and econometric RSCA index (symmetric revealed comparative advantage), has been demonstrated that increasing the comparative advantage between countries of ASEAN (Indonesia) + China and compete Japan's influence, which receives the support of increased production of increasingly de-specialization. And almost all ASEAN (Indonesia) + China began to change the economic and trade strategies of raw materials to manufacture (Tri Widodo: 2009).

In addition, the application of FTA (free trade agreement) and AIIB between ASEAN (Indonesia) + China has a beneficial impact for ASEAN, based on 3 factors: 


\section{Dinamika Global | Volume 02 | No.01 | Juni 2017}

1. Presence and network vertical FDI investment between China and Indonesia (ASEAN) member countries after AIIB

2. Any hope of economic growth in China for sustaining trade and economic development, when US and EU economy still in crisis

3. The difference between the varied economies of member countries of ASEAN (Indonesia) + China.

\section{2) China's Investment and Trade in Indonesia}

ASEAN has 602 million populations; roughly 250 million live in Indonesia, the most populous country in the bloc. In nominal GDP terms, Indonesia is the largest economy in ASEAN. Together with China and India, Indonesia is one of only three developing economies in Asia that are members of the Group of 20 (G20). The country's real GDP growth averaged 5.8 percent from 2003 through 2012, the fourth highest of all ASEAN members. However, Indonesia remains a relatively poor country: According to World Bank, GDP per capita was $\$ 3,475$ in 2013, placing it on the higher end of lower-middle-income countries. Indonesia struggles with poverty and unemployment, inadequate infrastructure, corruption, a complex regulatory environment, and unequal resource distribution among regions. At 13 percent of GDP, agriculture retains a large share of overall economic activity, while services account for a smaller share of GDP than industry (CIA World Fact Book: 2017).

Indonesia's trade-to-GDP ratio of 43 percent is one of the lowest in the ASEAN bloc. Unlike most of its neighbors, 


\section{Dinamika Global | Volume 02 | No.01 | Juni 2017}

Indonesia runs a goods trade deficit with the world. China represents Indonesia's second-largest export market and its largest source of imports (see Table 1). Along with Japan and Singapore, it is the primary contributor to Indonesia's trade deficit. This was not always the case: Table 2 shows the transition of Indonesia's trade balance with China from a surplus to a deficit, starting in 2007. Imports from China rose steadily from over $\$ 4$ billion in 2003 to $\$ 12.6$ billion in 2007 and increased to almost $\$ 37$ billion in 2013 (World Bank: 2017).

Table 1: Indonesia's Export and Import Partners in 2013

\begin{tabular}{|c|c|c|c|c|c|c|}
\hline & \multicolumn{2}{|c|}{ Exports } & & \multicolumn{3}{|c|}{ Imports } \\
\hline & $\begin{array}{c}\text { Value } \\
\text { (US\$ m) }\end{array}$ & $\begin{array}{c}\text { Share } \\
(\%)\end{array}$ & & & $\begin{array}{l}\text { Value } \\
\text { JS\$ m) }\end{array}$ & $\begin{array}{c}\text { Share } \\
(\%)\end{array}$ \\
\hline 1 Japan & $\$ 27,086$ & $14.8 \%$ & 1 China & $\$$ & 29,849 & $16.0 \%$ \\
\hline 2 China & $\$ 22,601$ & $12.4 \%$ & 2 Singapore & $\$$ & 25,581 & $13.7 \%$ \\
\hline 3 Singapore & $\$ 16,686$ & $9.1 \%$ & 3 Japan & $\$$ & 19,284 & $10.3 \%$ \\
\hline $4 \mathrm{US}$ & $\$ 15,741$ & $8.6 \%$ & 4 Malaysia & $\$$ & 13,322 & $7.1 \%$ \\
\hline 5 India & $\$ 13,031$ & $7.1 \%$ & 5 South Korea & $\$$ & 11,592 & $6.2 \%$ \\
\hline Other & $\$ 87,407$ & $47.9 \%$ & Other & $\$$ & 87,001 & $46.6 \%$ \\
\hline Total & $\$ 182,552$ & $100 \%$ & Total & $\$$ & 186,629 & $100 \%$ \\
\hline
\end{tabular}

Source: World Bank. 


\section{Dinamika Global | Volume 02 | No.01 | Juni 2017}

\section{Table 2: China's Goods Trade with Indonesia}

(US\$ millions)

\begin{tabular}{lrrrrrrrrrrr} 
& 2003 & 2004 & 2005 & 2006 & 2007 & 2008 & 2009 & 2010 & 2011 & 2012 & 2013 \\
\hline export & 4,482 & 6,257 & 8,349 & 9,453 & 12,609 & 17,210 & 14,744 & 21,978 & 29,263 & 34,293 & 36,947 \\
import & 5,754 & 7,212 & 8,430 & 9,610 & 12,380 & 14,387 & 13,538 & 20,760 & 31,323 & 32,033 & 31,479 \\
balance & $-1,272$ & -955 & -81 & -157 & 229 & 2,823 & 1,206 & 1,219 & $-2,059$ & 2,260 & 5,469
\end{tabular}

Source: China Ministry of Commerce, via CEIC database.

The composition of trade between China and Indonesia resembles a resources-for-manufactures pattern. Nearly half of Indonesia's imports from China are machinery and electrical products, to the extent that China constitutes one- third of Indonesia's foreign purchases in this category. Conversely, fuels, metals, wood, and vegetable products make up threequarters of Indonesia's exports to China, compared to 45 percent of its exports to the world. Along with Australia, Indonesia is a key supplier of coal and liquefied natural gas to China's energy-intensive coastal areas, which have difficulty accessing fuel inputs from China's northwestern regions. One could also group Indonesia with China's principal commodity suppliers in Africa and Latin America (World Bank: 2017). 
Figure 1: Breakdown of Indonesia's Trade with the World in 2013

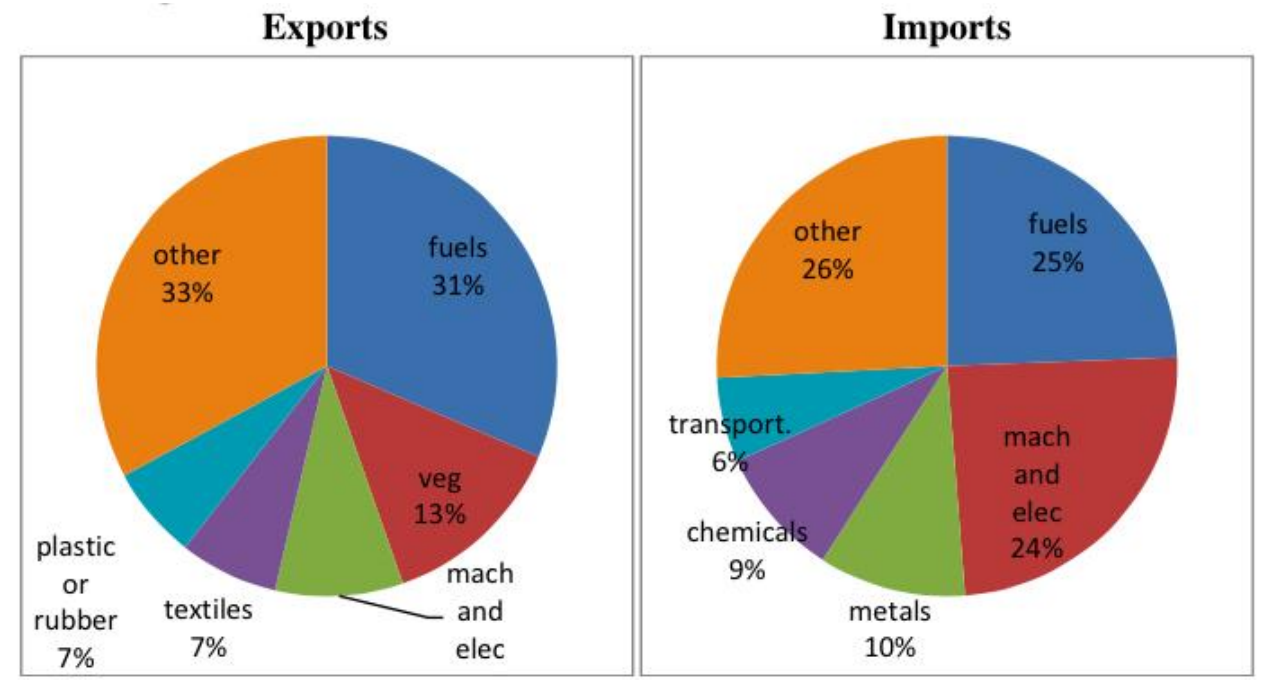

Note: Veg $=$ Vegetables.

Source: World Bank.

Figure 2: Breakdown of Indonesia's Trade with China in 2013

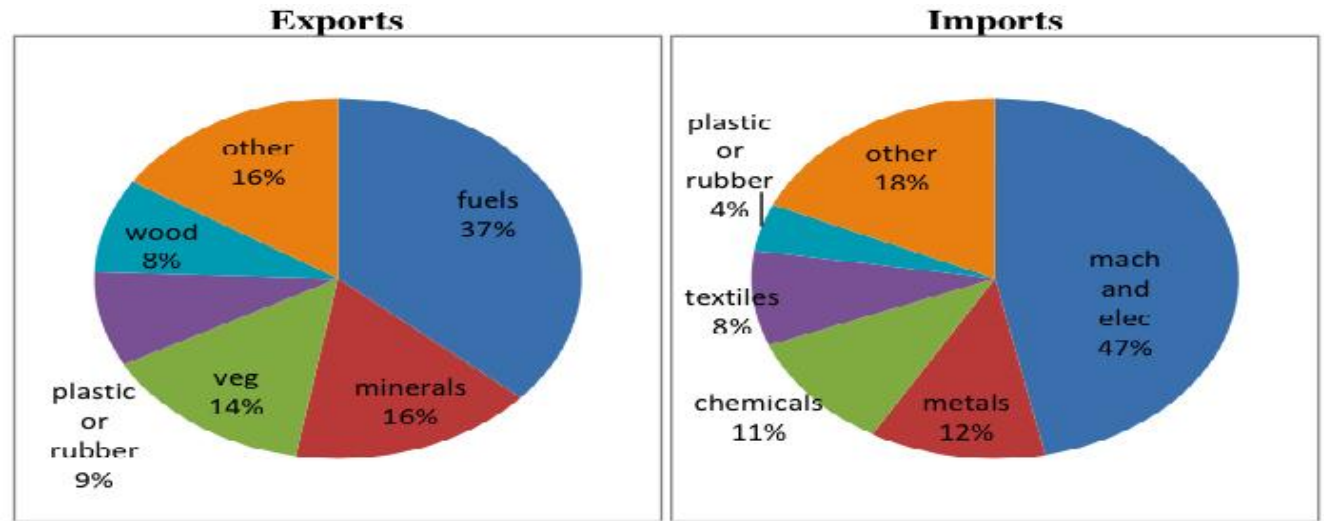

Note: Veg - Vegetables.

Source: World Bank. 


\section{Dinamika Global | Volume 02 | No.01 | Juni 2017}

Chinese outbound FDI into Indonesia has grown over the past decade (see Table 3), as China went from a net receiver to a net sender of FDI to Indonesia. The Heritage Global Investment Tracker, which traces individual Chinese investments, identifies dozens of Chinese investments and contracts in Indonesia between 2005 until 2016, with a combined worth of some $\$ 31.55$ billion, a huge amount of investment (The Heritage Global Investment Tracker: 2017).

Of this value, approximately $\$ 12$ billion went into the coal, gas, and oil sectors, and a further $\$ 6.6$ billion into the steel sector demonstrating the resource-seeking motives of Chinese investors in Indonesia (Nargiza Salidjanova and Iacob KochWeser: 2015).

Table 3: Stock of Chinese FDI in Indonesia

(US\$ millions)

\begin{tabular}{ccccccccccc}
2003 & 2004 & 2005 & 2006 & 2007 & 2008 & 2009 & 2010 & 2011 & 2012 & 2013 \\
\hline 54 & 122 & 141 & 226 & 679 & 543 & 799 & 1,150 & 1,688 & 3,098 & 4,657
\end{tabular}

Source: China Ministry of Commerce, via CFIC datahase. 


\section{Dinamika Global | Volume 02 | No.01 | Juni 2017}

3) Indonesia and China economic situation after AIIB cooperation

a) Positive Prediction

AIIB initiative is the establishment of a relevant step with the spirit of accelerating economic development and integration of Asia through the promotion of investment in the infrastructure sector. AIIB priority areas which include transportation, energy, communication, industry and agriculture are also becoming a priority in developing countries. Openness in terms of membership (open regionalism) is also showed that AIIB is not be managed exclusively by the emerging countries in Asia but also open to countries outside the region. Countries in the region can support the existence of AIIB with consideration of the financing gap for infrastructure financing where high financing needs cannot be met by the MDBs (Multi Development Banks), so AIIB can be as an alternative source of financing (Makmun Syadullah: 2014).

China's role in AIIB actually has worried many dominated countries in Asia, especially western economic power and its allied (US, EU, and Japan), there are some points why AIIB will give positive monetary environment in Asia, but agonize for western domination: A) China has created a regional bank among its Asian neighbors, in a move opposed by the Obama Administration. B) U.S. allies have sided with China despite Washington's concerns that China might be using the bank to circumvent more established international banks, such as the 


\section{Dinamika Global | Volume 02 | No.01 | Juni 2017}

World Bank and the International Monetary Fund, long dominated by the United States and Europe. C) China's supporters in the effort contend that their participation in the new bank will ensure greater transparency while avoiding China's tendency to loan money without protecting the environment, local populations, and clean governance (Sabrina Snell: 2015).

Though China is the gargantuan player in international trade, in investment China is still below of Japan, EU, and the USA though (see Table 4). Thus, China gradually shifting strategy from a passive to a more active role in the development of regional institutions and standards, and this trend is reflected in the newly-formed Asian Infrastructure Investment Bank (AIIB). And there is increased competition for spheres of influence within the region; however, the result will be more an overlapping of relationships and institutions, rather than the carving out of exclusive domains along the China-US divide (Bob Herrera-Lim, Andy Liu, Tobias Harris and Victor Cha: 2015). 


\section{Dinamika Global | Volume 02 | No.01 | Juni 2017}

Table 4: FDI Inflows in ASEAN

\begin{tabular}{|c|c|c|c|c|c|c|c|c|}
\hline \multirow{3}{*}{ Countryireg on ${ }^{v}$} & \multirow{2}{*}{\multicolumn{4}{|c|}{ Value }} & \multirow{2}{*}{\multicolumn{4}{|c|}{$\begin{array}{l}\text { value in JSs milicn share to total in percent } \\
\text { Stare :o total it flows }\end{array}$}} \\
\hline & & & & & & & & \\
\hline & $2012^{2 /}$ & $2013^{3 /}$ & $2014=/$ & $2012 \cdot 2014$ & $2012^{3}$ & $2013^{x}$ & 201<p! & $2012-2014$ \\
\hline Eurapean Union (E-) & 6.542 .3 & 22255.7 & 29.2685 & 58.066 .4 & 6.7 & 18.9 & 21.5 & 15.7 \\
\hline ASEAN & 20.548 .3 & $10,399.6$ & 24.3774 & $\$ 4.325 .8$ & 17.8 & 16.5 & 17.9 & 17.4 \\
\hline Japen & $21,206.1$ & $21,766.0$ & 13,3811 & 56,3633 & 18.4 & 18.5 & 9.8 & 15.3 \\
\hline UEA & 14.395 .8 & $4,913.3$ & $13,0<23$ & $32,36 \cdot 2$ & 12.5 & 4.2 & 2.6 & 8.8 \\
\hline Hong Kong & 2.480 .1 & 5.230 .2 & $9,504.9$ & 20.2153 & 4.7 & 4.4 & 7.0 & 5.5 \\
\hline Shine & $5,718.1$ & 6.7786 & 8.869 .4 & 21,3660 & 5.0 & 5.8 & 6.5 & 5.8 \\
\hline Pustral a & 3.219 .2 & 3.489 .2 & $5,703.4$ & $12,41 \cdot 8$ & 2.8 & 3.0 & 4.2 & 3.4 \\
\hline Repuzlc of Kores & $1,577.0$ & 3.652 .4 & 4.468 .9 & $9.6 \leq 8.3$ & .4 & 3.1 & 3.3 & 2.6 \\
\hline Tawen. Proy noe of Chira & 2938.2 & $1.3<9.9$ & 2.814 .1 & $7.0 \mathrm{C} 2.2$ & 2.5 & 1.1 & 2.1 & $1 . c$ \\
\hline Canasa & $1,043.0$ & $1,030.3$ & 1.264 .0 & 3.3422 & 0.9 & 0.9 & 0.9 & $0 . c$ \\
\hline Total top ter sources & 82573.5 & 89.365 .1 & 112.603 .9 & 255.1325 & 7.5 & 76.4 & 82.8 & 77.2 \\
\hline Dimis ${ }^{3}$ & 3?,A79.3 & 27,0219 & 23.4875 & $\pi 4.18 \Omega 7$ & 28.5 & 256 & 172 & $22 \mathrm{~F}$ \\
\hline Total FDI inflow to ASEAN & $115,452.8$ & $117,087.0$ & $136,181.4$ & $389,321.2$ & 100.0 & 100.0 & 100.0 & 100.0 \\
\hline Eouros AELAN Foreizr & $\begin{array}{l}\text { base se } \\
\text { dics (We }\end{array}$ & 15 (Jat & from s & LELAN & $\mathrm{Na}$ & 5 & SEL & \\
\hline
\end{tabular}

In spite of the fact that China's AIIB is challenging West Allied infrastructure investment domination (Bretton Wood Observer: 2014), global financial architecture (Robert Wihtol: 2015), new multilateralism and the erosion of the West (Thomas Renard: 2015), Potential economic game changer, and made China As a new major player in the world of multilateral development finance (geopolitically and reshaping world order) (EPSC Strategic Notes: 2015), but obviously ensure emerging power especially in Asia (including ASEAN) and particularly China to maintain and establish alternative for investment and infrastructure corridor independently, and it will become advantage for Indonesia which has US\$ 3,360.7 M capital subscription and 33,607 number of shares (Articles Agreement of AIIB: 2015). 


\section{b) Negative Prediction (Indonesia's more dependent to China)}

China important role as big trader (the international trade key actor/player which has at least $2 \%$ contribution in international trade/export and import) started in 1990s after trade domination core moved to Asia and in 2010 surpassed Germany and Japan to put China became the second number of international trade player under USA (Bayoumi: 2011). And in 2014 "China is a true mega-trader - a position last held by colonial Britain, with trade significant not only as a share of world trade (11.5\%) but also of its own GDP (47\%)" (Standard Chartered Special Report, 2014). China's share of the world has risen to $11.5 \%$ in 2012 from $7.5 \%$ in 2007 (See: Table 5)

Table 5: Merchandise Export as Shares of World Exports by

$$
\text { Mega-Trader, 1870-2030 }
$$

(percent)
\begin{tabular}{|l|r|r|r|r|r|}
\hline Year & United Kingdom & \multicolumn{1}{c|}{ Germany } & United States & \multicolumn{1}{c|}{ Japan } & \multicolumn{2}{|c|}{ China } \\
\hline 1870 & 24.3 & 13.4 & 5.0 & 0.1 & 2.8 \\
\hline 1913 & 18.5 & 18.0 & 9.0 & 0.8 & 2.0 \\
\hline 1929 & 15.1 & 16.6 & 14.4 & 2.1 & 3.0 \\
\hline 1950 & 10.2 & 3.9 & 16.2 & 1.3 & 0.9 \\
\hline 1973 & 5.1 & 12.9 & 12.2 & 6.4 & 1.0 \\
\hline 1990 & 5.3 & 12.0 & 11.3 & 8.2 & 1.8 \\
\hline 2000 & 4.4 & 8.5 & 12.1 & 7.4 & 11.2 \\
\hline 2012 & 2.6 & 7.7 & 8.4 & 4.4 & 12.1 \\
\hline $\begin{array}{l}2020 \\
\text { (projected) }\end{array}$ & 1.9 & 5.3 & 8.8 & 3.9 & 15.0 \\
\hline $\begin{array}{l}\text { 2030 } \\
\text { (projected) }\end{array}$ & 1.4 & 3.6 & 7.3 & 3.2 & \\
\hline
\end{tabular}

Source: Subramanian \& Kessler, 2013 


\section{Dinamika Global | Volume 02 | No.01 | Juni 2017}

China's main exports to Indonesia are manufacture products, machinery, and transportation tools. Meanwhile, China's main imports from Indonesia are raw materials (Oil and Coal) and investment destination (Poppy S. Winanti: 2015). Thus, only make Indonesia position similar to colonialism era as raw materials supplier and more dependent to China (Revrisond Baswir: 2015). Started in 2007, Indonesia trade relations to China always deficit (See: Table 6), and after AIIB, the condition will be more clear that Indonesia's position will be more dependent to China economic domination. Besides AIIB will make China get a bulk of infrastructure contracts, but Indonesia has complained about the construction standards of Chinese- built power plants (June Teufel Dreyer: 2015). Furthermore, China's infrastructure credibility should be asked to guarantee and transparency of the China quality commitment.

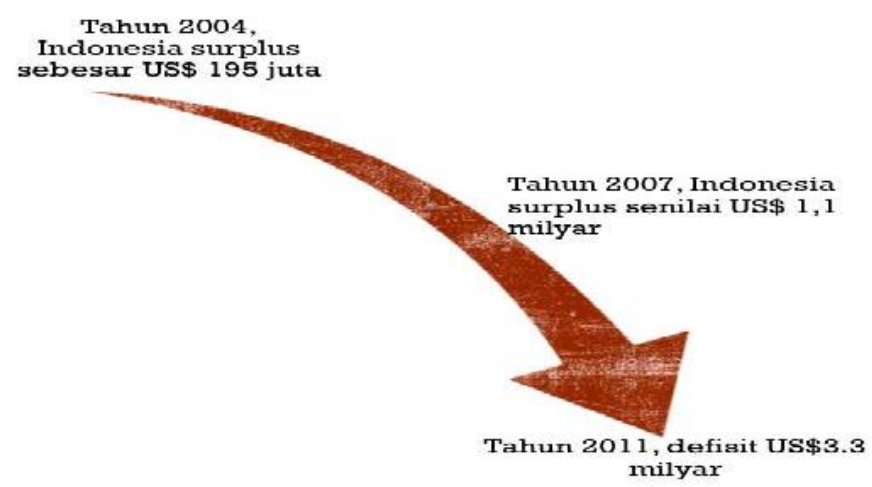


Table 6: Indonesia-China Trade Flows From 2004-Jan 2011 (in USD)

4) Conclusion

\begin{tabular}{cccc}
\hline Year & Export (E) & Import $(I)$ & Surplus / Deficit (E - I) \\
\hline $\mathbf{2 0 0 4}$ & $4,297,233,109$ & $4,101,331,096$ & $195,902,013$ \\
\hline $\mathbf{2 0 0 5}$ & $6,662,353,805$ & $\mathbf{5 , 8 4 2 , 8 6 2 , 5 1 3}$ & $819,491,292$ \\
\hline $\mathbf{2 0 0 6}$ & $8,343,571,337$ & $\mathbf{6 , 6 3 6 , 8 9 5 , 1 1 1}$ & $1,706,676,226$ \\
\hline $\mathbf{2 0 0 7}$ & $9,675,512,723$ & $\mathbf{8 , 5 5 7 , 8 7 7 , 1 2 1}$ & $1,117,635,602$ \\
$\mathbf{2 0 0 8}$ & $11,636,503,721$ & $15,247,168,927$ & $(3,610,665,206)$ \\
\hline $\mathbf{2 0 0 9}$ & $11,499,327,261$ & $14,054,809,205$ & $(2,555,481,944)$ \\
\hline $\mathbf{2 0 1 0}$ & $14,080,900,000$ & $19,688,000,000$ & $(5,607,100,000)$ \\
\hline Jan-10 & $1,010,900,000$ & $1,406,000,000$ & $(395,100,000)$ \\
\hline Jan-11 & $1,152,700,000$ & $1,815,200,000$ & $(662,500,000)$ \\
\hline
\end{tabular}

Source: the Central Statistics Agency (BPS)

China after AIIB has double-edged influence for Indonesia, the positive's side Indonesia has an alternative for infrastructure and economic development besides various Multi Development Banks (MDBs) that already existed such as IMF, $\mathrm{ADB}, \mathrm{IDB}$, and WB. It means Indonesia will be less dependent on West economic condition and affection. But on the other hands, China's hegemonic economy power gradually put Indonesia's position more determined to them.

Some negative conditions above, due to the major problems and challenges of the economic performance of Indonesia's diplomacy, among others, do not have a clear strategy, and without the infrastructure support and strong fundament policies, as well as weak on domestic readiness for the challenges and demands of the international political-economy dynamics (Dinar Henrika Sinurat, 2015). 


\section{Dinamika Global | Volume 02 | No.01 | Juni 2017}

Weak conditions in Indonesia related to the international political-economy diplomacy has deep roots and not solely because of the method or the management of diplomacy which does not reflect national interests, but also related to the paradigm of thinking and way of life of the nation that has not adhered more with the character of the Indonesian values (Pancasila and Constitutions)

The strong currents of globalization characterized by the interconnected and integrated world have made sovereign borders between countries are increasingly blurred. This process facilitates capital inflows in every aspect of the region to accelerate the process of liberalization and capitalization of political-economic-social-cultural aspects (Manfred Stegger, 2003). And especially in the economy only makes Indonesia a mere supplier of raw materials needs and market destination, the actual form was not much different from the conditions of Indonesia when still in the grip of colonialism.

Indonesia is inseparable from colonialism whichever survived for 350 years, and colonialism is a matter related to lose or profit colony, colonialism is not a matter of courtesy or about the obligations, this problem is a matter of finding life, about business or corporation who seeks life/profit (Sukarno, 1928).

According to Sukarno, Indonesia entered the colonial economic system if the Indonesian economy; first, merely positioned as a supplier of raw materials for the developed 
industrial countries. Second, the Indonesian economy serves as a product market by industrialized developed countries. And third, the Indonesian economy serves as a place to play the advantages of capital in countries that are rich industrialized. And conditions such as Sukarno picture that is being faced by Indonesia at this time.

To address this, it needs a comprehensive solution, which is characterized by structural (top-down) and cultural (bottomup), therefore the repair process occurs in two directions. The first to perform a structural correction of the colonial economy that was still here in Indonesia through amendments of 1945 Constitution, and the Law is still pro the actions of colonialism/capitalism, and structural changes in the politicaleconomic system to directs Indonesia returned to the people's sovereignty, which is understood as a democratic economy (Revrisond Baswir, 2015).

The Democratic economy itself is an economic democracy, where economic engagement is not only controlled by the owners of capital (capitalist) but all elements of society. Democratic economy arranged on the principle of kinship, it is the cooperative principle of family, so Indonesia in international relations is not only talking about free-trade but should speak related cooperation/collaboration, not competition (Muhammad Hatta, 1977). Hopes that will affect the way of Indonesia's foreign policy point of view shifts in people's interest, no longer national interest or commodity interest, because the national 


\section{Dinamika Global | Volume 02 | No.01 | Juni 2017}

interest and the commodity itself are controlled by the mafia/capitalist or oligarchy.

While the culture solution is a solution that requires a long process, because it is more to the public self-awareness that Indonesia needs to have a strong cultural character, hence not to be eroded by the influence of globalization. Cultural awareness of the community itself is actually more important and fundamental (basic structure), due to influence the mindset and actions of the public directly. This fact has been touted by Trisakti, which is politic sovereignty, independent of the economy, and personality in culture (Sukarno, 1963). Which then try reappointed by President Jokowi through a mental revolution movement in accordance with his Nawacita, hopefully. 
Bibliography

$\underline{\text { Books }}$

Articles Agreement of AIIB

(2015).

https://www.aiib.org/en/about-aiib/basic-

documents/_download/articles-of-

agreement/basic_document_english-

bank_articles_of_agreement.pdf

Bob Herrera-Lim, Andy Liu, Tobias Harris and Victor Cha (2015). Asia: The AIIB and The Region - Competition, Not Confrontation. Teneo Intelligence.

Chang Jae Lee (2008). "Characteristic and prospects for East Asian economic integration: a Korean perspective". Springer Science+Business Media, Vol. 41: 331-344.

Dinar Henrika Sinurat (2015). Forum Kebijakan Luar Negeri: "Penguatan Kinerja Diplomasi Ekonomi Indonesia dalam Menghadapi Perkembangan Rezim Investasi dan Perdagangan Internasional".

Donghyun Park, Inwon Park dan Gemma Esther B. Estrada (2012). "The Prospects of ASEAN-Korean Free Trade Area (AKFTA): A Qualitative and Quantitative Analysis". ASEAN Economic Bulletin, Vol. 29: 29-45.

EPSC Strategic Notes (2015). The Asian Infrastructure Investment Bank. A New Multilateral Financial Institution or a Vehicle for China's Geostrategic Goals. European Political Strategy Centre. https://ec.europa.eu/epsc/sites/epsc/files/strategic_not e_issue_1.pdf

Makmun Syadullah (2014). Prospects of Asian Infrastructure Investment Bank. Journal of Social and Development Sciences.

Manfred B. Stegger (2003). Globalization: A Very Short Introduction. Oxford University Press, UK. 


\section{Dinamika Global | Volume 02 | No.01 | Juni 2017}

Mohammad Hatta (1977). Persoalan Ekonomi Sosialis Indonesia. Penerbit Djambatan.

Nargiza Salidjanova and Iacob Koch-Weser (2015). China's Economic Ties with ASEAN: A Country-By-Country Analysis. US-China Economic and Security Review Commission: Staff Research Report.

Nathapornpan Piyaareekul Uttama dan Nicolas Peridy. (2010). "Foreign Direct Investment and Productivity Spillovers: the Experience of ASEAN Countries" Journal of Economic Integration, Center for Economic Integration, Sejong University, Vol 25: 298-323.

Poppy S. Winanti (2015). Forum Kebijakan Luar Negeri: "Penguatan Kinerja Diplomasi Ekonomi Indonesia dalam Menghadapi Perkembangan Rezim Investasi dan Perdagangan Internasional".

Revrisond Baswir (2015). Forum Kebijakan Luar Negeri: "Penguatan Kinerja Diplomasi Ekonomi Indonesia dalam Menghadapi Perkembangan Rezim Investasi dan Perdagangan Internasional".

Robert Wihtol (2015). Beijing's Challenge to the Global Financial Architecture.

https: / / asianstudies.georgetown.edu/sites/asianstudies/ files/GJAA\%202.1\%20Wihtol\%2C\%20Robert_0.pdf

Sabrina Snell (2015). US Allies Split with Washington, Bank with China. US-China Economic and Security Review Commission: Staff Research Report.

Tamim Bayoumi (2011). Changing Patterns of Global Trade. https://www.imf.org/external/np/pp/eng/2011/061511. pdf

Thomas Renard (2015). The Asian Infrastructure Investment Bank (AIIB): China's new multilateralism and the erosion of the West. Security Policy Brief. http://aei.pitt.edu/64789/1/SPB63-Renard.pdf 


\section{Dinamika Global | Volume 02 | No.01 | Juni 2017}

Toby Kendall and Cillian Ryan (2009). "Regional Economic Integration, Mergers and FDI: Welfare and Policy Implication for ASEAN" Springer-Verlag, 223-246

Tri Widodo (2009). "Dynamic Comparative Advantages in the ASEAN+3 ". Journal of Economic Integration, 24: 505-529.

V. Rodriguez and A. Soeparwata (2012). "The Governance of Science, Technology and Innovation in ASEAN and Its Member States”. Springer Science+Business Media, 1-22.

Woosik Moon (2011). Whither East Asian economic integration?, Korea's regionalization cum globalization strategy. Springer-Verlag, Vol $9: 29-42$.

\section{Media Online}

Bretton Wood Observer (2014). The rise of the infrastructure giants: World Bank's infrastructure hegemony challenged in

Asia.

http://www.brettonwoodsproject.org/2014/06/riseinfrastructure-giants/.

Data World Bank (2017), diunduh pada tanggal: 2 November 2017, http://www.worldbank.org.

Data World CIA Factbook (2017), diunduh pada tanggal: 2 November 2017, https://www.cia.gov/index.html.

Heritage

Global

Investment

Tracker.http:://www.heritage.org/research/projects /chin a-global-investment-tracker-interactive-map.

Sukarno (1928). Pledoi: Indonesia Menggugat. http://www.berdikarionline.com/soekarno-menggugatimperialisme/.

June Teufel Dreyer (2015). The Asian Infrastructure Investment Bank: Who Will Benefit. Foreign Policy Research Institute. https://www.fpri.org/article/2015/04/the-asianinfrastructure-investment-bank-who-will-benefit/. 
Zhang Monan (2015), assistant researcher of China Center for International Economic Exchanges, Different roles of Asian Infrastructure Investment Bank, di unduh pada tanggal: 1 November 2017 http:/ / english.cntv.cn/2015/03/19/ARTI142675797405 0912.shtml. 